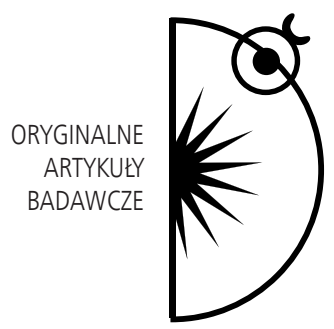

Wioletta Tuszyńska-Bogucka

Jacek Bogucki

Dominika Dziduch

\title{
Satysfakcja i poczucie własnej wartości u kobiet w różnych typach związków
}

DOI: http://dx.doi.org/10.12775/PBE.2013.013

łączenie się w pary jest zakodowane w biologicznej konstrukcji człowieka $i$ w jego naturze

M. K. Hinchliffe, D. Hooper, F. J. Roberts, Melancholia matżeńska

\section{Wstęp}

Odpowiedzią społeczeństwa na biologiczne potrzeby jednostki była $\mathrm{i}$ jest instytucja małżeństwa. Obok niej zawsze istniały jednak związki nieformalne, które nie tyle ze względów prawnych, co z uwagi na dezaprobatę społeczną stanowiły zjawisko marginalne i nieujawniane. Współczesna modernizacja oraz indywidualizacja społeczeństwa obejmuje swym szerokim zasięgiem wydarzenia zarówno o charakterze psychologicznym, strukturalnym, jak i kulturowym, co nadaje nowe znaczenie życiu prywatnemu jednostek. W dzisiejszych czasach w społeczeństwie funkcjonują różne style życia, a na przełomie ostatnich lat wyraźnie zwiększył się repertuar tzw. związków alternatywnych - konkubenckich, związków typu friends, rodzin patchworkowych, rodzin nomadycznych, związków typu LAT (Living Apart Together) czy LTA (Living Together 
Apart), tzw. związków DINKS (double income, no kids), a w końcu - osób świadomie pozostających poza związkami, tzw. singli. Zmieniają się także wzorce zachowań seksualnych (Trost, 1978; Villeneuve-Gokalp, 1991; Prinz, 1995; Kiernan, 2002; Hoft, Goldberger, 2006; Szczot, 2008). Ponadto, nastąpiło opóźnianie wieku zawierania małżeństw i czasu rodzenia pierwszego dziecka. Jednocześnie nasila się problem osób o orientacji homoseksualnej, związany $\mathrm{z}$ żądaniem równouprawnienia tworzonych przez nie związków w stosunku do małżeństwa i rodzin.

Dzieje się tak, gdyż - jak twierdzą badacze - przestały obowiązywać zakazy i nakazy wynikające $\mathrm{z}$ dawnego ładu społeczno-kulturowego, a w miejsce starych norm pojawiły się nowe wartości oraz wyznaczniki postępowania. Jednostki zaczęły dążyć do autonomii i zostały uwolnione od tradycyjnych zobowiązań, pojawiły się nowe reguły egzystowania, oparte na samorefleksyjności (Jabłoński, Ostasz, 2001; Slany, 2002; Kwak, 2005; Szukalski, 2004, 2006; Janicka, 2002, 2008a, 2008b, 2008c; Matysiak, 2009; Szczepankiewicz-Battek, Formela, 2010; Juszczyk-Frelkiewicz, 2011; Tuszyńska-Bogucka, 2011) oraz na dopasowaniu rozwiązania do indywidualnej sytuacji życiowej czy też preferencji.

Obecnie obserwuje się wzrastającą popularność związków niemałżeńskich. „W wyniku indywidualizacji wzrosła liczba dopuszczalnych moralnie i praktycznie wyborów, gdy chodzi o formę życia [...], modernizacja postuluje indywidualizm, samorealizację i autonomię lub przynajmniej pewną formę wolności od autokratycznej kontroli wewnątrz rodziny" (Kwak, 2005, s. 23-24). Owa wolność wyboru i nieustanne dopasowywanie się do aktualnych potrzeb samorealizacyjnych i społecznych sprawia, że procesy przemian dotykają najsilniej właśnie rodzinę, zarówno jej płaszczyznę strukturalną (zewnętrzną), jak i wymiar interakcji wewnątrzrodzinnych. Jej model, kiedyś uznawany za tak oczywisty, w dzisiejszych czasach przestaje być jedynym i słusznym ze względu na wzrost alternatywnych form związków.

Niekoniecznie świadczy to jednak o anarchii i zaniku więzi. Mimo kwestionowania instytucji małżeństwa i rodziny, młodzi ludzie nie dążą za wszelką cenę do życia bez związków (wspomnianej już wcześniej „singlizacji” życia), zmiany zachowań seksualnych są normowane, a stabilne partnerstwo - cenione, chociaż niekoniecznie ludzie dążą do jego legalizacji (Kwak, 2005; Tuszyńska-Bogucka, 2011). Widać więc, że mimo iż rodzina nuklearna przestaje spełniać swoje funkcje, to nie przestaje istnieć w ogóle, a raczej przekształca się w nowy system, który inaczej zaspokaja potrzeby jednostek XXI wieku. „Kształty rodziny będą zatem formowane poprzez subiektywne relacje z kulturą i będą uza- 
leżnione od subiektywnych pragnień, przekonań czy stanu psychiki człowieka" (Kawula, 2007, s. 8).

\section{Współczesne tendencje przemian rodziny oraz formy alternatywne dla małżeństwa}

Współcześni badacze wskazują przede wszystkim na dwa główne trendy tychże przemian w ostatnich dekadach. Pierwszy, można go nazwać ewolucyjnym, to powstawanie neotradycyjnej rodziny, która jest inną, ale nie stuprocentowo zmienioną wersją rodziny tradycyjnej, a raczej pewną jej wariacją. Pod uwagę brane są tu przede wszystkim zmiany dotyczące funkcjonowania: powroty kobiet po urodzeniu dziecka do pracy, urlopy ojcowskie, zmiany tradycyjnych ról płciowych, powtórne małżeństwa osób rozwiedzionych, kohabitacje i wszelkie innego typu niezamężne stosunki seksualne traktowane jako dłuższa faza przejściowa związku przedmałżeńskiego (tzw. małżeństwo na próbę) opóźniająca zawarcie związku małżeńskiego (Kwak, 2005, za: Elliot, 1986), który z reguły jednak w takich sytuacjach następuje (Slany, 2002). Zwolennicy tego poglądu uważają, że system rodzinny oparty na małżeństwie jest tak wysoce uprzywilejowany zarówno prawnie, jak i społecznie, że alternatywne formy życia oraz wydłużenie się okresu kohabitowania nie mają większego znaczenia i nie stanowią zagrożenia dla trwania instytucji małżeństwa jako takiej.

Drugi, bardziej rewolucyjny, kierunek społecznych i kulturowych przemian rodziny zakłada istnienie pewnego rodzaju rewolucji transformacyjnej życia rodzinnego, zarówno pod względem struktury, jak i charakteru relacji osób weń uczestniczących, jednak zjawisko to jest traktowane i interpretowane odmiennie przez przedstawicieli różnych orientacji naukowych oraz - światopoglądowych. Według liberałów, tak jak i tradycjonalistów, jest to równoznaczne z kompletną dezintegracją porządku społecznego na płaszczyźnie rodziny jako formy zinstytucjonalizowanej. Jednak, o ile przedstawiciele nurtu uznającego tradycyjne formy związków uważają to za zjawisko nader niekorzystne, o tyle drudzy - liberałowie (często utożsamiani, aczkolwiek nie zawsze całkiem słusznie, z tzw. postmodernistami ${ }^{1}$ ), jako zwolennicy tego rodzaju przemian, głoszą pogląd, iż tradycyjna rodzina jest uciążliwą oraz zbankrutowaną insty-

\footnotetext{
${ }^{1}$ Centralnym zagadnieniem i tematem w postmodernizmie jest opozycja pomiędzy pojęciem „nowoczesności” i „,ponowoczesności”. Postmodernistyczni teoretycy piszą o końcu człowieka, o zmianie jego kondycji, podają w wątpliwość wszelkie systemy wartości jako arbitralne i determinujące człowieka. Postmodernizm wiąże się z poczuciem lęku przed modernizmem utożsamianym z systemami totalitarnymi. Współczesne poglądy na strukturę i funkcję małżeństwa tzw. ba-
} 
tucją i wyrażają zadowolenie z powodu możliwego jej zaniku w dotychczasowej formie. Według nich transformacja umożliwiła dokonywanie wyborów form życia rodzinnego. Podstawowym i zarazem głównym argumentem zwolenników drugiego trendu przemian rodziny jest fakt, iż obecnie wchodzi się w tzw. związki wolne, bez zobowiązań materialnych oraz formalnych, zaś najważniejszymi cechami takiego związku jest jego okresowość oraz partnerstwo na zasadach równouprawnienia (Kwak, 2005).

Jedną z bardziej obecnie rozpowszechnionych form związku jest związek kohabitacyjny. Tworzą go jednostki będące w stanie wolnym, ale żyjące razem. Choć nie jest konieczne posiadanie wspólnego budżetu, często pary żyjące ze sobą w związkach kohabitacyjnych taki ustalają. Nie posiadają one przywilejów prawnych (Ruszkiewicz 2008).

Związki te są różnie oceniane. $Z$ jednej strony jako jedno $\mathrm{z}$ największych współczesnych zagrożeń rodziny, o czym świadczy np. cytat: „wszystkie te sytuacje według Katechizmu znieważają godność małżeństwa i niszczą samo pojęcie rodziny poprzez osłabienie znaczenia wierności. Są one sprzeczne z prawem moralnym, gdyż akt płciowy powinien mieć miejsce wyłącznie w małżeństwie" (Szczot, 2013, on-line). Z drugiej strony jako świadomie wybierane i tworzone relacje, niezagrażające wartościom uniwersalnym, lecz budujące wolność i dobrostan jednostki (Szczepankiewicz-Battek, Formela, 2010). Pomimo tych rozbieżności w ocenie związki kohabitacyjne są coraz częściej spotykaną formą współżycia i wydaje się, iż stanowią one konieczny obszar eksploracji naukowych.

\section{Materiał i metoda}

Inspiracją do przeprowadzenia badań jest fakt, iż związki kohabitacyjne wydają się być jedną z najpowszechniej obecnie spotykanych form związku alternatywnego w stosunku do związków sformalizowanych. Interesujące wydaje się także sprawdzenie, na ile sprawdzą się raportowane w licznych dotychczasowych badaniach konkluzje dotyczące negatywnego wpływu okresu kohabitacji na funkcjonowanie osobiste tworzących taki związek jednostek oraz późniejszych etapów związku następujących po formalizacji w porównaniu z małżeństwami niepoprzedzonymi takim etapem (Laskowski, 1987; Jankowiak, 2007; Slany, 2002; Podolska, Sipak-Szmigiel, 2010; Janicka, 2006, 2008a, 2008b,

daczy nurtu liberalnego zakładają zaś, iż nie ma dominującej formy rodziny, jest tylko rosnący pluralizm, jak twierdził np. Smart (1998). 
2009). W niniejszym projekcie badawczym autorzy skupili swoją uwagę na satysfakcji ze związku oraz poczuciu własnej wartości, a więc zmiennych dotychczas rzadko podejmowanych w eksploracjach naukowych funkcjonowania osób pozostających w różnych typach związków, a ważnych z punktu widzenia ich następstw dla trwałości związku (Rostowski, 1987; Plopa, 1995).

W celu uniknięcia założenia wartościującego w pracy zadano więc jedynie pytania badawcze, bez domniemania stanu rzeczy w hipotezach. Autorzy przyjęli wobec tego, iż praca będzie mieć charakter eksploracyjny, i postawili w niej następujące pytania badawcze:

1. Czy kobiety zamężne i kohabitujące różnią się stopniem nasilenia poziomu satysfakcji ze związku (w zakresie intymności, rozczarowania, podobieństwa, samorealizacji, wsparcia, zaangażowania oraz deprecjacji)?

2. Czy kobiety zamężne i kohabitujące różnią się stopniem nasilenia poczucia własnej wartości (w zakresie ogólnej samooceny, kompetencji, poczucia popularności, poczucia bycia kochaną, zdolności przywódczych, samokontroli, samoakceptacji moralnej, poczucia atrakcyjności fizycznej, witalności, integracji tożsamości oraz obronnego wzmocnienia samooceny)?

W badaniu wzięło udział 67 kobiet, z czego do próby zakwalifikowano 30 kobiet kohabitujących oraz 30 kobiet zamężnych. Wszystkie kobiety mieścily się w przedziale wiekowym od 21 do 46 lat. Staż związków, zarówno formalnych, jak i nieformalnych, wynosił od 6 miesięcy do 18 lat. Kobiety zostały przebadane trzema rodzajami kwestionariuszy, które mierzyły zarówno nasilenie zmiennych głównych: samoocena, poczucie własnej wartości oraz poziom nasilenia satysfakcji ze związku, jak i ich składowych: Wielowymiarowy Kwestionariusz Samooceny MSEI O’Briena i Epsteina w adaptacji Fecenec (2008); Kwestionariusz Dobranego Małżeństwa Plopy (2008) oraz Kwestionariusz Komunikacji Małżeńskiej Kaźmierczak i Plopy (Plopa 2008). 
Tabela 1. Analiza istotności różnic międzygrupowych dla podskal kwestionariusza $\operatorname{KDM}(\mathrm{n}=30)$

\begin{tabular}{|c|c|c|c|c|c|}
\hline Zmienna & Stan cywilny & M & SD & $\begin{array}{l}\text { Wartość testu T } \\
\text { Studenta }\end{array}$ & $\begin{array}{l}\text { Poziom } \\
\text { istotności } \\
\text { różnic }\end{array}$ \\
\hline \multirow[t]{2}{*}{ Intymność } & $\begin{array}{l}\text { Kobiety niezamężne } \\
\text { kohabitujące }\end{array}$ & 34,4 & 4,28 & \multirow[t]{2}{*}{2,972} & \multirow[t]{2}{*}{0,001} \\
\hline & Kobiety zamężne & 29,9 & 7,09 & & \\
\hline \multirow[t]{2}{*}{ Rozczarowanie } & $\begin{array}{l}\text { Kobiety niezamężne } \\
\text { kohabitujące }\end{array}$ & 18,53 & 4,96 & \multirow[t]{2}{*}{$-1,602$} & \multirow[t]{2}{*}{0,002} \\
\hline & Kobiety zamężne & 21,56 & 9,11 & & \\
\hline \multirow[t]{2}{*}{ Samorealizacja } & $\begin{array}{l}\text { Kobiety niezamężne } \\
\text { kohabitujące }\end{array}$ & 26,3 & 4,64 & \multirow[t]{2}{*}{$-0,069$} & \multirow[t]{2}{*}{ n. i. } \\
\hline & Kobiety zamężne & 26,4 & 6,48 & & \\
\hline \multirow[t]{2}{*}{ Podobieństwo } & $\begin{array}{l}\text { Kobiety niezamężne } \\
\text { kohabitujące }\end{array}$ & 29,7 & 2,91 & \multirow[t]{2}{*}{3,540} & \multirow[t]{2}{*}{0,001} \\
\hline & Kobiety zamężne & 25,73 & 5,4 & & \\
\hline \multirow{2}{*}{ Wynik ogólny } & $\begin{array}{l}\text { Kobiety niezamężne } \\
\text { kohabitujące }\end{array}$ & 108,93 & 8,5 & \multirow{2}{*}{1,068} & \multirow{2}{*}{ (tendencja) } \\
\hline & Kobiety zamężne & 103,6 & 11,21 & & \\
\hline
\end{tabular}

Analiza wyników w tabeli 1 ukazuje ich zróżnicowanie w poszczególnych skalach Kwestionariusza Dobranego Matżeństwa. Średnia wartość w kategoriach, w których odnotowano różnice istotne statystycznie lub z tendencją do zróżnicowania, okazała się wyższa w grupie kobiet niezamężnych kohabitujących, oprócz skali „rozczarowanie”, gdzie wynik był wyższy dla grupy mężatek. Okazuje się, że pomiędzy wynikami, uzyskanymi przez badane grupy w skalach „intymność”, „rozczarowanie” oraz „podobieństwo” zachodzą różnice istotne statystycznie. W skali „wynik ogólny” widoczna jest tendencja do zróżnicowania. W skali „samorealizacja” różnica okazała się nieistotna statystycznie na poziomie 0,05 . 
Tabela 2. Analiza istotności różnic międzygrupowych dla podskal kwestionariusza $\operatorname{KKM}(n=30)$

\begin{tabular}{|c|c|c|c|c|c|}
\hline Zmienna & Stan cywilny & $M$ & SD & $\begin{array}{l}\text { Wartość } \\
\text { testu T } \\
\text { Studenta }\end{array}$ & $\begin{array}{l}\text { Poziom } \\
\text { istotności } \\
\text { różnic }\end{array}$ \\
\hline \multirow{2}{*}{$\begin{array}{l}\text { Wsparcie - ocena } \\
\text { własnych zachowań }\end{array}$} & $\begin{array}{l}\text { Kobiety niezamężne } \\
\text { kohabitujące }\end{array}$ & 45,66 & 4,11 & \multirow[t]{2}{*}{1,570} & \multirow{2}{*}{ n. i. } \\
\hline & Kobiety zamężne & 43,3 & 5,57 & & \\
\hline \multirow{2}{*}{$\begin{array}{l}\text { Zaangażowanie - } \\
\text { ocena własnych } \\
\text { zachowań }\end{array}$} & $\begin{array}{l}\text { Kobiety niezamężne } \\
\text { kohabitujące }\end{array}$ & 37,03 & 3,91 & \multirow[t]{2}{*}{2,634} & \multirow[t]{2}{*}{0,02} \\
\hline & Kobiety zamężne & 33,93 & 5,11 & & \\
\hline \multirow{2}{*}{$\begin{array}{l}\text { Deprecjacja - ocena } \\
\text { własnych zachowań }\end{array}$} & $\begin{array}{l}\text { Kobiety niezamężne } \\
\text { kohabitujące }\end{array}$ & 23,26 & 5,90 & \multirow[t]{2}{*}{0,842} & \multirow[t]{2}{*}{ n. i. } \\
\hline & Kobiety zamężne & 22,00 & 5,74 & & \\
\hline \multirow{2}{*}{$\begin{array}{l}\text { Wsparcie - ocena } \\
\text { zachowań partnera }\end{array}$} & $\begin{array}{l}\text { Kobiety niezamężne } \\
\text { kohabitujące }\end{array}$ & 44,76 & 4,59 & \multirow[t]{2}{*}{2,862} & \multirow[t]{2}{*}{0,01} \\
\hline & Kobiety zamężne & 39,56 & 8,83 & & \\
\hline \multirow{2}{*}{$\begin{array}{l}\text { Zaangażowanie - } \\
\text { ocena zachowań } \\
\text { partnera }\end{array}$} & $\begin{array}{l}\text { Kobiety niezamężne } \\
\text { kohabitujące }\end{array}$ & 37,33 & 4,97 & \multirow[t]{2}{*}{3,542} & \multirow[t]{2}{*}{0,001} \\
\hline & Kobiety zamężne & 31,46 & 7,58 & & \\
\hline \multirow{2}{*}{$\begin{array}{l}\text { Deprecjacja - ocena } \\
\text { zachowań partnera }\end{array}$} & $\begin{array}{l}\text { Kobiety niezamężne } \\
\text { kohabitujące }\end{array}$ & 20,10 & 6,40 & \multirow[t]{2}{*}{$-1,903$} & \multirow[t]{2}{*}{0,05} \\
\hline & Kobiety zamężne & 22,73 & 10,69 & & \\
\hline
\end{tabular}

Analizując wyniki uzyskane w teście KKM (tab. 2), można stwierdzić, iż średnie wartości wyników okazały się wyższe w grupie mężatek w wynikach w skali deprecjacji - ocena zachowań partnera, zaś z kolei w grupie kobiet kohabitujących w skalach: zaangażowanie - ocena zachowań partnera i wsparcie - ocena zachowań partnera. Różnice istotne statystycznie odnotowano pomiędzy wynikami w skalach: wsparcie - ocena zachowań partnera, zaangażowanie - ocena zachowań partnera, deprecjacja - ocena zachowań partnera. 
Tabela 3. Analiza istotności różnic międzygrupowych dla podskal kwestionariusza MSEI $(n=30)$

\begin{tabular}{|c|c|c|c|c|}
\hline Zmienna & Stan cywilny & M & SD & $\begin{array}{l}\text { Wartość testu } \\
\text { T Studenta* }^{*}\end{array}$ \\
\hline \multirow{2}{*}{ Ogólna samoocena } & Kobiety niezamężne kohabitujące & 34,76 & 6,1 & \multirow{2}{*}{0,935} \\
\hline & Kobiety zamężne & 33,3 & 6,04 & \\
\hline \multirow[t]{2}{*}{ Kompetencje } & Kobiety niezamężne kohabitujące & 38,06 & 5,61 & \multirow[t]{2}{*}{1,483} \\
\hline & Kobiety zamężne & 35,73 & 6,53 & \\
\hline \multirow{2}{*}{ Bycie kochaną } & Kobiety niezamężne kohabitujące & 40,5 & 5,86 & \multirow{2}{*}{0,837} \\
\hline & Kobiety zamężne & 38,93 & 8,41 & \\
\hline \multirow{2}{*}{ Popularność } & Kobiety niezamężne kohabitujące & 37,83 & 4,65 & \multirow{2}{*}{1,328} \\
\hline & Kobiety zamężne & 36,16 & 5,05 & \\
\hline \multirow{2}{*}{$\begin{array}{l}\text { Zdolności } \\
\text { przywódcze }\end{array}$} & Kobiety niezamężne kohabitujące & 34,93 & 5,80 & \multirow{2}{*}{1,605} \\
\hline & Kobiety zamężne & 32,56 & 5,61 & \\
\hline \multirow{2}{*}{ Samokontrola } & Kobiety niezamężne kohabitujące & 34,7 & 6,90 & \multirow{2}{*}{0,572} \\
\hline & Kobiety zamężne & 35,6 & 5,14 & \\
\hline \multirow{2}{*}{$\begin{array}{l}\text { Samoakceptacja } \\
\text { moralna }\end{array}$} & Kobiety niezamężne kohabitujące & 42,9 & 4,55 & \multirow{2}{*}{1,115} \\
\hline & Kobiety zamężne & 41,4 & 5,79 & \\
\hline \multirow[t]{2}{*}{ Atrakcyjność fizyczna } & Kobiety niezamężne kohabitujące & 35,83 & 6,28 & \multirow{2}{*}{1,444} \\
\hline & Kobiety zamężne & 33,13 & 8,08 & \\
\hline \multirow{2}{*}{ Witalność } & Kobiety niezamężne kohabitujące & 35,73 & 6,88 & \multirow{2}{*}{0,966} \\
\hline & Kobiety zamężne & 33,8 & 8,52 & \\
\hline
\end{tabular}

*Różnice nieistotne na poziomie 0,05 .

Przedstawione wyniki badań dla Wielowymiarowego Kwestionariusza Samooceny MSEI wskazują (tab. 3), że brak jest istotnych statystycznie różnic pomiędzy wynikami uzyskanymi $\mathrm{w}$ obu badanych grupach we wszystkich podskalach tego narzędzia badawczego. Warto nadmienić jednak, iż w każdej z ośmiu podskal kwestionariusza MSEI: ogólna samoocena, kompetencje, 
bycie kochaną, popularność, zdolności przywódcze, samoakceptacja moralna, atrakcyjność fizyczna, witalność, wartości średnich były wyższe dla grupy niezamężnych kobiet kohabitujących a jedynie w kategorii „samokontrola” nieco wyższy wynik osiągnęły mężatki.

\section{Wnioski - dyskusja - perspektywa badawcza}

Na wstępie należy zaznaczyć, iż niniejsza praca nie jest pisana ani z konserwatywnej, ani liberalnej perspektywy ujmowania rodziny. Jest z założenia obiektywnym psychologicznym studium porównawczym kobiet funkcjonujących w jednej z najbardziej rozpowszechnionych obecnie form związku alternatywnego - związku kohabitacyjnym - oraz mężatek. Takie badania wydają się bardzo przydatne wobec istniejącej na gruncie polskim, jak stwierdzają Jabłoński i Ostasz (2002), tendencji badaczy do reprezentacji „silnego sądu życzeniowo-powinnościowego" (Jabłoński, Ostasz, 2002, s. 13), dotyczącego trwania jednego małżeństwa przez całe życie, a prace takie „fundowane na silnym założeniu wartościującym mają ograniczoną wartość poznawczą" (Jabłoński, Ostasz, 2002, s. 14). Wymienieni autorzy zwracają uwagę, że w polskiej nauce dominuje koncentracja na tzw. idealnym wymiarze kultury, a przecież tylko śledzenie tzw. kultury realnej pozwala dostrzec rolę oraz rzeczywisty charakter kohabitacji.

Współczesne badania wykazały, że niektóre cechy osobowości i zachowania osób mieszkających z partnerem przed ślubem mogą utrudniać funkcjonowanie w związku trwałym. Są to na przykład: neurotyzm, niska samoocena, gorsza umiejętność komunikacji i współpracy, trudności w konsekwentnym realizowaniu swoich planów (Slany 2002). Wskazuje się wręcz na związek pomiędzy stanem cywilnym kobiety a ryzykiem wystąpienia depresji poporodowej (Podolska, Sipak-Szmigiel, 2010). Janicka na podstawie badań własnych formułuje jednoznaczne wnioski, że związki niemałżeńskie (nienastawione na prokreację, zakładające niezależność ekonomiczną, co sprzyja porzuceniu dotychczasowego partnera) stanowią zagrożenie dla rozwoju jednostki i rodziny. Twierdzi ona także, że partnerzy kohabitujący ujawniają mniejszą niż małżonkowie zależność od siebie oraz są mniej efektywni w pozyskiwaniu i dostarczaniu wsparcia. Najważniejszy wydaje się jednak wniosek o niższym u par nieformalnych niż u małżeństw poczuciu bezpieczeństwa, a nawet zmniejszaniu się go w miarę wydłużającego się stażu związku. Autorka przypisuje również kohabitującym kobietom niepewność, niepokój, a nawet izolację w stopniu, który stanowi zagrożenie dla ich zdrowia psychicznego, co nazywane bywa „efektem kohabi- 
tacji” (cohabitation'effect). Badania autorki dowiodły, że w związkach kohabitacyjnych poziom zadowolenia partnerów spada wraz z wydłużeniem się stażu relacji. Takiej tendencji nie zaobserwowano u małżeństw, co ma dowodzić, że są one bardziej stabilne pod względem zadowolenia. Przy zastosowaniu regresji logistycznej wykazano, że staż kohabitacji zwiększa ryzyko niezadowolenia ze związku także w przyszłości, stąd takie związki są bardziej zagrożone dezintegracją (Janicka, 2006, 2008a, 2009). Sygnalizuje się także, iż przedmałżeńska kohabitacja ujemnie koreluje z jakością związku (Laskowski, 1987; Jankowiak, 2007).

Analiza zebranego materiału pozwoliła na sformułowanie wniosku, iż kobiety zamężne i kohabitujące, które uczestniczyły w prezentowanych badaniach, nie różniły się stopniem nasilenia poczucia własnej wartości. Badane kobiety, zarówno kohabitujące, jak i zamężne, wykazały podobny poziom nasilenia: ogólnej samooceny, kompetencji, popularności, bycia kochaną, zdolności przywódczych, samokontroli, samoakceptacji moralnej, atrakcyjności fizycznej, witalności i integracji psychicznej.

Kobiety zamężne i kohabitujące różniły się stopniem nasilenia poczucia satysfakcji ze związku, w którym przebywają. Różnice te dotyczą przede wszystkim kilku czynników grupujących więzi małżeńskie/partnerskie. Podobieństwo i intymność partnerów były ocenione jako wyższe w grupie kobiet niezamężnych kohabitujących w porównaniu z grupą badanych mężatek. Oznacza to, że badane związki kohabitacyjne w percepcji ich uczestniczek charakteryzowały się wysokim (istotnie wyższym w porównaniu z grupą kobiet zamężnych) poziomem zaangażowania ze strony partnerów w rozwój tegoż związku. Partnerzy w tego typu związkach byli w odbiorze drugiej strony bardziej wrażliwi na jej potrzeby oraz istniał $w$ ich przypadku wyższy poziom zgodności co do realizowania ważnych dla związku celów, zarówno w obrębie przestrzeni psychicznej, jak i granic zewnętrznych, np. spędzania wolnego czasu. Świadczy to również o tym, że odczuwalna bliskość emocjonalna, zbieżność światopoglądów i podobieństwo cech psychicznych była większa w grupie kobiet kohabitujących, co jest nie lada paradoksem w świetle dotychczasowych badań nad tym rodzajem związków.

Wynik taki, przemawiający w pewnym sensie na korzyść badanych związków niesformalizowanych, można tłumaczyć być może zwiększoną motywacją partnerów do podtrzymywania dobrych relacji, szukania kompromisów oraz chęcią dbałości o rozwijający się dobrze związek w sytuacji, w której nie mają oni gwarancji na jego utrzymanie, a którą zdaje się w ich oczach charakteryzować instytucja małżeństwa. Być może przed ślubem, ze względu 
na większą ilość rozrywek zapewnianych związkowi w celu jego podtrzymania i uatrakcyjnienia, jest także po prostu więcej okazji, w których partnerzy mogą skonfrontować swoje potrzeby, mają też czas zarezerwowany na to, aby te potrzeby zaspokajać - w efekcie czego dochodzi do określenia wysokiego poziomu zgodności realizacji pewnych celów. Spadek satysfakcji ze związku w aspekcie podobieństwa partnerskiego u kobiet zamężnych można tłumaczyć pojawianiem się nowych, często trudnych sytuacji, wymagających współdziałania na innej niż dotychczas (czyli przed ślubem) płaszczyźnie, np. wychowanie potomstwa, ustalanie wspólnych wydatków, planowanie budżetu, dzielenie czasu pomiędzy obowiązki domowe, aktywność zawodową a opiekę nad dziećmi, co może sprawiać, że pojawiają się sytuacje konfliktowe. Waga obszarów życia, na których występują te konflikty, sprawia, że spada poziom zdolności do zawierania kompromisów, co z kolei obniża odczuwalną satysfakcję ze związku, nie tylko w aspekcie podobieństwa cech partnerów, ale i w innych, np. odczuwania poziomu intymności w byciu w bliskiej relacji $\mathrm{z}$ drugą osobą.

Jak pokazują uzyskane wyniki, grupa kobiet kohabitujących wykazała wysoki, a przynajmniej wyższy w porównaniu mężatkami poziom satysfakcji z bycia w bliskiej relacji z partnerem. Kobiety te częściej i silniej odczuwały, że łączy ich z partnerem prawdziwe uczucie oparte na miłości, otwarciu, bliskości, zaufaniu, miały też większe od mężatek poczucie szczęścia. Prawdopodobnie łączy się to z ich motywacją do pracy na rzecz dobra związku, w którym przebywają; zdolnością, a przede wszystkim chęcią do kompromisów, większą ugodowością, empatią i zwiększoną wrażliwością na potrzeby partnera współkohabitującego (przecież o związek, który jest satysfakcjonujący, dba się starannie), co może mieć pierwszorzędne znaczenie dla jakości związku i odczuwanej satysfakcji.

Kobiety kohabitujące odczuwały istotnie większe nasilenie wsparcia i zaangażowania ze strony partnera w porównaniu z grupą mężatek. Oznacza to, że badane kohabitantki od partnera otrzymywały więcej zrozumienia, ciepła, częściej niż wobec mężatek były im okazywane uczucia i pozytywne emocje. Kobiety niezamężne częściej otrzymywały od swoich partnerów aktywną pomoc przy rozwiązywaniu problemów oraz poparcie w ważnych sprawach w obliczu sytuacji konfliktu ze światem zewnętrznym. Były one także częściej chwalone i nagradzane. Częściej niż mężatki wypracowywały kompromisy w negocjacjach rodzinnych. Partnerzy kohabitantek częściej podkreślali wyjątkowość i atrakcyjność swoich partnerek. W badaniach nie potwierdziło się 
więc założenie, iż związki kohabitacyjne, które opierają się m.in. na wygodzie, mogą kolidować z procesem starania się o względy osoby, którą kochamy.

Mężatki odczuwały mniejsze zaangażowanie dla ich spraw i całego związku ze strony partnerów oraz nie doświadczały tak wysokiego wsparcia i troski z ich strony w porównaniu z grupą kobiet niezamężnych. Mężatki wykazały z kolei większe nasilenie deprecjacji ze strony partnera. Taka deprecjacja siebie może przejawiać się na różne sposoby i mieć różny stopień natężenia - od dewaluujących wypowiedzi, przez określone postępowanie, aż po rozwiązania związane nawet z aktami agresji. Przykładem tego może być nadmierne przypisywanie innym winy za niepowodzenia przez osoby posiadające taką skłonność, i to niezależnie od tego, czy naprawdę są one odpowiedzialne za daną sytuację. Innym, jawnym przejawem dewaloryzowania i deprecjonowania są wszelkie oskarżenia itp. Oprócz braku poszanowania godności innych do zachowań deprecjacyjnych należą również: kontrola działań, próby dominacji, narzucanie innym własnego zdania i wymuszanie pewnych zachowań zgodnych z oczekiwaniami własnymi. Być może takie właśnie zachowania czy też aroganckie zachowania, złośliwości dnia codziennego oraz wybuchy złości, przy jednoczesnym braku ciepła, zaangażowania i bliskości ze strony męża, może być skutkiem tego, iż mężatki wykazały w badaniu istotnie wyższe od kohabitantek wyniki pod względem poziomu rozczarowania związkiem i partnerem. Być może dla niektórych z nich taki układ jest odczytywany jako życiowa porażka. W takiej sytuacji, kiedy narasta deprecjacja i rozczarowanie i brakuje pozytywnych przejawów dbałości o związek, satysfakcja z małżeństwa spada. Trzeba podkreślić, iż z punktu widzenia rozwojowego kryzysy w małżeństwie są nieuniknione. Związek, który po formalizacji jest w pewien sposób zmuszony do przeobrażenia się z romantycznego $\mathrm{w}$ praktyczno-zabezpieczający, musi zmierzyć się z szeregiem punktów ważnych, często spornych właśnie ze względu na swoją rangę i istotność dla obojga osób. Frustracja i rozczarowanie, w pewnej dozie, są więc raczej nieuniknione.

Pomimo spadku satysfakcji ze związku pod względem jakości komunikacji oraz bliskości odczuwanych więzi ze współmałżonkiem warto podkreślić, iż mężatki te nie miały zaniżonej samooceny w porównaniu z grupą kohabitujących kobiet. Wyniki pokazują, że pomimo iż kobiety z grupy kohabitujących uzyskiwały wyższe wyniki w ośmiu na dziewięć aspektów pomiaru samooceny, żadna $\mathrm{z}$ tych liczbowych przewag nie występuje na poziomie istotnym (mowa jest tu o: ogólnej samoocenie, kompetencjach, byciu kochaną, popularności, zdolnościach przywódczych, samoakceptacji moralnej, atrakcyjności fizycznej, 
witalności). W skali samokontrolowania się mężatki uzyskały nieco wyższy wynik od kobiet niezamężnych. Wraz ze wzrostem samokontroli rośnie samoakceptacja moralna, integracja tożsamości oraz ogólna samoocena. Wynik ten sugeruje, iż nie ma takich sfer funkcjonowania codziennego, w których mężatki mogłyby mieć niższą samoocenę w porównaniu z grupą kobiet niezamężnych. Ich globalny wizerunek samych siebie pozostaje niezachwiany pomimo obniżonej satysfakcji ze związku małżeńskiego w niektórych płaszczyznach.

Podsumowując, można stwierdzić, że kobieca samoocena i poczucie własnej wartości, badane $\mathrm{w}$ prezentowanym projekcie, nie zależały od tego, w jakim związku przebywały badane - w sformalizowanym (małżeńskim) czy niesformalizowanym (kohabitacyjnym). Jest to logiczne, gdyż poczucie własnej wartości jest to wewnętrznie ustrukturalizowany stan psychiczny, traktowany jako skutek własnej oceny, na którą wpływa oszacowanie własnych umiejętności dla nas ważnych oraz ich pozytywna weryfikacja w naszym życiu. Zasadniczo zatem poczucie własnej wartości jest trwałym i afektywnym poczuciem pewności siebie, opartym na właściwej percepcji własnej osoby (Zaborowski 1998; Branden 2007).

Choć nie było to bezpośrednim przedmiotem badań, można stwierdzić, niejako interpretując badane zjawiska i ich wymowę, iż niepokojący jest fakt, iż wydaje się, że poziom satysfakcji ze związku po ślubie spada, a kobiety wybierające kohabitację cieszą się jej wyższym poziomem. Jednakże należy pamiętać, że jest to na pewno naturalny proces ewolucji związku, do którego przyczyniają się zmiany w postaci urodzenia dziecka, konieczności dzielenia wielu obowiązków itp. Prawdopodobne skutki tych zmagań, a więc odczuwalny brak zaangażowania, wsparcia, podobieństwa oraz intymności, a także doświadczanie deprecjacji ze strony partnera, z pewnością nie przyczynią się do polepszenia jakości związku. Poziom komunikacji małżeńskiej ma tu niewątpliwie znaczenie pierwszorzędne, może on albo utrzymywać na dobrym poziomie poczucie satysfakcji ze związku lub też, przez stosowanie niewłaściwego komunikowania się, może osłabiać więzy rodzinne oraz powodować rozdźwięk pomiędzy małżonkami.

Powyższe badania nie wyczerpują oczywiście wszystkich aspektów związanych z samopoczuciem współczesnych mężatek oraz kobiet pozostających w kohabitacji. Istnieje wiele kierunków badań, mogących zgłębić problematykę tego zagadnienia, a także pomysłów projektów badawczych. Istnieje także kilka czynników, które mogły wpłynąć na ograniczenie i wady przeprowadzonego badania. Należałoby przede wszystkim zwiększyć liczebność grup 
badawczych, poszerzyć zakres analiz, np. o analizę współzmienności między badanymi obszarami, a także analizy wielozmiennowe. Być może dokonanie analizy zróżnicowania wyników uzyskiwanych pod kątem takich zmiennych jak zawód, wykształcenie czy liczba dzieci także wniosłoby możliwość sformułowania bardziej szczegółowych wniosków. Ciekawe byłoby także, i potrzebne, przeprowadzenie badań nad percepcją mężczyzn pozostających w związkach kohabitacyjnych oraz małżeńskich. Otrzymane wyniki mogłyby przyczynić się do rozwoju badań w dziedzinie psychologii rodziny, a tym samym wspomóc psychologów rodziny w diagnozowaniu i rozwiązywaniu problemów rodziny współczesnej, tak aby kohabitacja była krokiem w kierunku małżeństwa lub świadomego partnerstwa, a nie tylko wygodnym testem na sprawdzenie dopasowania, czyli pejoratywnym odpowiednikiem „związku na próbę”.

\section{Bibliografia}

Branden N. (2007), Jak dobrze być sobą. O poczuciu własnej wartości, GWP, Gdańsk.

Fecenec D. (2008), MSEI - Wielowymiarowy Kwestionariusz Samooceny, PTP, Warszawa.

Hoft S., Goldberger M. (2006), Oficjalne kochanki, oficjalni kochankowie. O gościnności seksualnej, wymianie malżonków, niewierności, cicisbizmie w różnych kulturach, Wyd. Adiaphora, Olsztyn.

Jabłoński D., Ostasz L. (2001), Zarys wiedzy o rodzinie, małżeństwie, kohabitacji i konkubinacie: perspektywa antropologii kulturowej i ogólnej, Adiaphora, Olsztyn.

Janicka I. (2002), Przeobrażenia współczesnego małżeństwa, „Acta Universitatis Lodziensis, Folia Psychologica UŁ”, nr 6, s. 3-13.

Janicka I. (2006), Kohabitacja a matżeństwo w perspektywie psychologicznej. Studium porównawcze, Wyd. Uniwersytetu Łódzkiego, Łódź.

Janicka (2008a), Staż wspólnego życia a satysfakcja seksualna partnerów kohabitujących, „Psychologia Rozwojowa”, nr 4, s. 37-48.

Janicka I. (2008b), Dynamika związku a wzajemna zależność kohabitujących partnerów, w: M. Bogdanowicz, M. Lipowska (red.), Rodzinne, edukacyjne i psychologiczne wyznaczniki rozwoju, Oficyna Wydawnicza Impuls, Kraków, s. 71-83.

Janicka I. (2008c), Stosunki partnerskie w związkach niematżeńskich, „Przegląd Psychologiczny", nr 1, s. 37-53.

Janicka I. (2009), Ryzyko kryzysów i konfliktów z związkach kohabitacyjnych, „Przegląd Psychologiczny", nr 1, s. 293-308. 
Juszczyk-Frelkiewicz K. (2011), The Social Need for Cohabitation Relationships. Sociological Approach, "The New Educational Review”, nr 24 (2), s. 397-403.

Kawula S. (2007), Dyskurs wokót pedagogiki i pedagogii rodziny, „Kultura i Edukacja”, nr 3, s. 7-23.

Kiernan K. (2002), Cohabitation in Western Europe: trends, issues and implications, w: Booth A., Crouter A. (red.), Just Living Together: Implications of Cohabitation on Families, Children and Social Policy, Lawrence Erlbaum Associates, New York, s. $3-31$.

Kwak A. (2005), Rodzina w dobie przemian. Matżeństwo i kohabitacja, Wyd. Akademickie Żak, Warszawa.

Laskowski, J. (1987), Trwałość wspólnoty matżenskiej: studium socjo-psychologiczne, Wyd. OdiSS, Warszawa.

Matysiak, A. (2009), Is Poland really "immune" to the spread of cohabitation?, "Demographic Research”, No. 21, s. 215-234.

Plopa M. (2005), Psychologia rodziny. Teoria $i$ badania, Oficyna Wydawnicza Impuls, Kraków.

Plopa M. (2008), Więzi w matżeństwie i rodzinie. Metody badań, Oficyna Wydawnicza Impuls, Kraków.

Rostowski J. (1987), Zarys psychologii małzeństwa: psychologiczne uwarunkowania dobranego zwiąku, Wydawnictwo Naukowe PWN, Warszawa.

Podolska M., Sipak-Szmigiel O. (2010), Stan cywilny a nasilenie objawów depresji okotoporodowej wśród kobiet ciężarnych, „Annales Academiae Medicae Stetinensis”, nr 56 (1), s. 87-92.

Prinz C. (1995), Cohabiting, Married or Single, Avebury, England.

Ruszkiewicz D. (2008), Życie w pojedynkę-ucieczka od rodziny czy znak naszych czasów, Wyd. Wyższej Szkoły Humanistyczno-Ekonomicznej, Łódź.

Slany K. (2002), Alternatywne formy życia matżésko-rodzinnego w ponowoczesnym świecie, Zakład Wydawniczy Nomos, Kraków.

Smart B. (1998), Postmodernizm, seria Kluczowe Idee.,Wyd. Zysk i S-ka, Poznań.

Szczepankiewicz-Battek J., Formela K. (2010), Zwiazki partnerskie - deprecjacja tradycyjnych wartości czy prawa człowieka?, w: Semkow J., Wojtaś J. (red.), Rzeczywistość międzykulturowa z perspektywy pedagogiki integralnej, Państwowa Wyższa Szkoła Zawodowa im. Witelona w Legnicy, Legnica, s. 249-267.

Szczot E. (2008), Wspótczesne zagrożenia matżeństwa i rodziny. Wybrane aspekty prawno-kanoniczne, w: Tymosz S. (red.), Matzeństwo i rodzina wobec wspótczesnych wyzwań, Wyd. KUL, Lublin, s. 75-76. 
Szczot E. (2013), Rodzina a wolne zwiazki. Skutki kanoniczne i społeczne deprecjacji rodzi$n y$, ,Biuletyn SAWP KUL”, nr 4. http://www.sawp.org.pl/index.php?option=com_co ntent\&view=article\&id=55:rodzina-a-wolne-zwizki-skutki-kanoniczne-i-spoecznedeprecjacji-rodziny\&catid=14:nr-4\&Itemid=25

Szukalski P. (2004), Kohabitacja w Polsce, w: Warzywoda-Kruszyńska W., Szukalski P. (red.), Rodzina w zmieniającym się spoleczeństwie polskim, Wyd. Uniwersytetu Łódzkiego, Łódź, s. 49-74.

Szukalski P. (2006), Przestrzenne zróżnicowanie związków kohabitacyjnych $w$ Polsce, w: Szukalski P. (red.), Szansa na sukces. Recepty współczesnych Polaków, Wyd. UŁ, Łódź, s. 19-36.

Trost J. (1978), A renewed social institution: non-marital cohabitation, „Acta Sociologica”, nr 21 (4), s. 303-315.

Tuszyńska-Bogucka W. (2011), W poszukiwaniu źródeł współczesnych przemian stylu życia. Przeszłość rodzinna , singli” oraz osób, pozostajacych w zwiazkach, „Przegląd Badań Edukacyjnych", nr 13 (2), s. 53-77.

Villeneuve-Gokalp C. (1991), From marriage to informal union: recent changes in the behaviour of French couples, "Population: An English Selection", No. 3, s. 81-111.

Zaborowski Z. (1998), Świadomość i samoświadomość człowieka, Wyd. Psychologii i Kultury Eneteia, Warszawa.

\section{Satisfaction and self-esteem in women in different types of relations}

\section{Summary}

In view of the numerous reports, suggesting a negative effect of the informal relation (cohabitation) to the functioning of individuals attempt to obtain answers to questions or wives and woman in informal relations shows different levels of satisfaction of the relationship (intimacy, disappointment, similarity, self-realization, support, commitment and depreciation) and the severity of self-esteem (in general self-esteem, competence, a sense of popularity, a sense of being loved, leadership skills, self-control, moral self-acceptance, a sense of physical attractiveness, vitality, identity integration, and strengthen self-defense)? The study of two groups of women who remain in cohabitation relationships and marriages $(\mathrm{n}=30)$, using the Multidimensional Self-Assessment Questionnaire by E. J. O'Briena and S. Epstein in adapting D. Fecenec; Matching Marriage Questionnaire by M. Plopa and Marital Communication Questionnaire by A. Kaźmierczak and M. Plopa showed that the wives and woman in informal relationships did not differ in the severity of self-esteem. The non-married cohabiting and married showed similar levels of severity: a general self-esteem, competence, popularity, being loved, leadership skills, self-control, moral self-acceptance, sense of physical 
attractiveness, vitality and mental integration. Women in informal relationships showed different levels and severity of satisfaction from the relation in which they live. The similarity and intimacy partners were rated as higher in unmarried women in informal relationship compared with married women. This means that the tested relationships in the perception of cohabiting women in informal relationships were characterized by a significantly higher level of involvement of the partners in the development of the relationship in comparison with married women.

Keywords: type of relationship, cohabitation, satisfaction, self-esteem. 